\title{
Non-genomic action of resveratrol on androgen and oestrogen receptors in prostate cancer: modulation of the phosphoinositide 3-kinase pathway
}

\author{
DA Benitez', E Pozo-Guisado², M Clementi', E Castellón' and PM Fernandez-Salguero*,2 \\ 'Laboratorio de Andrología Celular y Molecular, PDFB, ICBM, Facultad de Medicina, Universidad de Chile, P.O. Box 70005, Santiago de Chile, Chile; \\ ${ }^{2}$ Departamento de Bioquímica y Biología Molecular, Facultad de Ciencias, Universidad de Extremadura, 06080, Badajoz, Spain
}

Prostate cancer represents a major concern in human oncology and the phytoalexin resveratrol (RES) inhibits growth and proliferation of prostate cancer cells through the induction of apoptosis. In addition, previous data indicate that in oestrogenresponsive human breast cancer cells, RES induces apoptosis by inhibition of the phosphoinositide-3-kinase (PI3K) pathway. Here, using androgen receptor (AR)-positive LNCaP and oestrogen receptor alpha (ER $\alpha$ )-expressing PC-3 prostate tumour cells, we have analysed whether the antiproliferative activity of RES takes place by inhibition of the AR- or ER $\alpha$-dependent PI3K pathway. Although RES treatment (up to $150 \mu \mathrm{M}$ ) decreased AR and ER $\alpha$ protein levels, it did not affect AR and ER $\alpha$ interaction with p85-PI3K. Immunoprecipitation and kinase assays showed that RES inhibited AR- and ER $\alpha$-dependent PI3K activities in LNCaP and PC-3, respectively. Consistently, lower PI3K activities correlated with decreased phosphorylation of downstream targets protein kinase B/ AKT (PKB/AKT) and glycogen synthase kinase-3 (GSK-3). GSK-3 dephosphorylation could be responsible for the decreased cyclin D I levels observed in both cell lines. Importantly, RES markedly decreased PKB/AKT phosphorylation in primary cultures from human prostate tumours, suggesting that the mechanism proposed here could take place in vivo. Thus, RES could have antitumoral activity in androgen-sensitive and androgen-non-sensitive human prostate tumours by inhibiting survival pathways such as that mediated by PI3K.

British Journal of Cancer (2007) 96, I595- 1604. doi: I0.1 038/sj.bjc.6603755 www.bjcancer.com

Published online 8 May 2007

(c) 2007 Cancer Research UK

Keywords: resveratrol; prostate cancer; PI3K pathway; androgen receptor; oestrogen receptor; GSK-3

Trans-resveratrol $\left(3,4^{\prime}, 5\right.$-trihydroxystilbene, RES) is a phytoalexin that has gained considerable interest because of its ability to inhibit cell proliferation in tumour cells of different origin (Ahmad et al, 2001; Dorrie et al, 2001; Joe et al, 2002; Pozo-Guisado et al, 2002). In vivo, several studies have shown that RES inhibits tumour growth in xenograft mouse models for skin (Jang et al, 1997), mammary gland (Banerjee et al, 2002; Whitsett et al, 2006) and colorectal (Sengottuvelan et al, 2006) cancer. Particularly, interesting is the effect of RES as a selective apoptotic inducer in tumour cells that respond to steroid hormones. Thus, previous studies have revealed that RES triggered apoptosis in oestrogen receptor alpha $(\mathrm{ER} \alpha)$-positive MCF-7 but not in ER $\alpha$-negative MDA-MB-231 human breast tumour cells. These specific effects were associated to cell type-specific regulation of proteins controlling the G1/S (cyclin D1, cyclin E) and G2/M (cyclin B, $\mathrm{cdc} 2^{\mathrm{p} 34}$ ) transitions of the cell cycle (Lu and Serrero, 1999; PozoGuisado et al, 2002). The $\mathrm{ER} \alpha$ is not only a transcriptional regulator in the cell nucleus but also a cytosolic intermediate in the survival pathway regulated by phosphoinositide-3-kinase (PI3K)

*Correspondence: Dr PM Fernandez-Salguero; E-mail: pmfersal@unex.es Received 22 December 2006; revised 26 March 2007; accepted 26 March 2007; published online 8 May 2007
(Simoncini et al, 2000; Marquez and Pietras, 2001; Cantley, 2002). Based on these observations, we previously reported that the apoptosis induced by RES in oestrogen-dependent MCF-7 cells was mediated by inhibition of the ER $\alpha$-associated PI3K activity (Pozo-Guisado et al, 2004). Further, this effect involved a caspaseindependent mechanism with downregulation of Bcl-2 and NF- $\kappa \mathrm{B}$ (Pozo-Guisado et al, 2005). Several studies reported that RES has a complex effect in oestrogen-responsive cells, acting as antagonist or agonist for the ER $\alpha$ in different cell types and cellular contexts (Gehm et al, 1997; Lu and Serrero, 1999; Basly et al, 2000; Bowers et al, 2000; Bhat et al, 2001; Levenson et al, 2003; Pozo-Guisado et al, 2004).

Among PI3Ks, those belonging to the IA class are composed of a regulatory subunit $(\mathrm{p} 85 \alpha)$ and a catalytic peptide (p110). Functionally, p85 $\alpha$ links membrane-bound growth factor receptors to p110, which synthesises lipid intermediates such as phosphatidylinositol-3,4,5-triphosphate $\left(\mathrm{PI}(3,4,5) \mathrm{P}_{3}\right)$ (Cantley, 2002). $\mathrm{PI}(3,4,5) \mathrm{P}_{3}$ functions as a docking molecule for the membrane localisation of proteins harbouring pleckstrin homology domains such as protein kinase B/AKT (PKB/AKT) (Stephens et al, 1998). One of relevant target proteins of $\mathrm{PKB} / \mathrm{AKT}$ is glycogen synthase kinase-3 (GSK-3), which becomes inactivated by PKB/AKTdependent phosphorylation (Cross et al, 1995). In unstimulated cells (e.g. low PKB/AKT activity), active GSK-3 phosphorylates 
proteins such as cyclin D1, c-myc and glycogen synthase, thus promoting their degradation and leading to downregulation of the cell cycle. Under conditions of PI3K activation, PKB/AKT phosphorylates and inactivates GSK-3, which results in increased levels of metabolic and cell cycle regulatory proteins that will drive the G1/S transition (Scheid and Woodgett, 2001; Scheid et al, 2002). As over-activation of the PI3K pathway has been linked to human disease, a better knowledge of its molecular intermediates in different cell types could help to find novel targets and to characterise new therapeutic molecules against human cancer (Scheid and Woodgett, 2001).

The effects of RES on different steroid hormone-responsive tumour cells appear to follow a common mechanism. Similar to that observed in ER $\alpha$-positive MCF-7 breast tumour cells, RES inhibited DNA synthesis and modulated cell cycle progression in androgen receptor (AR)-positive $\mathrm{LNCaP}$ but not in AR-negative DU145 human prostate tumour cells (Hsieh and $\mathrm{Wu}, 1999$; Kuwajerwala et al, 2002). Recent studies have also shown that AR status could cause a differential effect of RES on cell cycle regulation at the G1/S transition in LNCaP and PC-3 cells (Benitez et al, 2007). Moreover, RES modulated the transcriptional activity of the AR in LNCaP prostate cancer cells (Mitchell et al, 1999; Gao et al, 2004), inducing changes in gene expression (Narayanan et al, 2003) that were similar to those observed after inhibiting the transcriptional activity of the ER $\alpha$ in MCF-7 breast tumour cells (Pozo-Guisado et al, 2004). Finally, the interaction of steroid hormone receptors with PI3K is not exclusive of the $\mathrm{ER} \alpha$, as the AR can also activate this kinase by forming a complex with p85 and Src (Sun et al, 2003). In a recent study, Aziz et al (2006) reported that RES decreased PKB/AKT phosphorylation in LNCaP cells and associated this effect with the induction of apoptosis by the intrinsic mitochondrial pathway. Interestingly, a similar correlation has been proposed for apoptosis induction by RES in MCF-7 breast cancer cells, in which inhibition of PI3K resulted in lower $\mathrm{PKB} / \mathrm{AKT}$ activity, NF- $\kappa \mathrm{B}$ inhibition and Bcl-2 downregulation (Pozo-Guisado et al, 2004; Pozo-Guisado et al, 2005).

Based on these previous results, it appears that RES triggers specific mechanisms of apoptosis in a cell type selective manner in steroid hormone-responsive breast and prostate cancer cells. In this work, we have used LNCaP (AR positive, $\mathrm{ER} \alpha$ negative) and PC-3 (AR negative, ER $\alpha$ positive) prostate tumour cells to address the mechanism through which RES modulates the AR- and ER $\alpha$ associated PI3K activity. We have found that RES inhibited, in a concentration-dependent manner, AR- and ER $\alpha$-dependent PI3K activity in LNCaP and PC-3, respectively. PI3K inhibition correlated with $\mathrm{PKB} / \mathrm{AKT}$ and GSK-3 phosphorylation and with decreased cyclin D1 levels. Further, RES also inhibited PKB/AKT phosphorylation in cultured cells from primary human prostate tumours. We suggest that AR and ER $\alpha$-associated PI3K could represent novel target proteins for the antitumoral activity of RES in human prostate tumours, establishing a common mechanism with other hormone-dependent cancers such as breast.

\section{MATERIALS AND METHODS}

\section{Reagents}

RES, dihydrotestosterone (DHT), $17 \beta$-oestradiol (E2), ATP, L- $\alpha$ phosphatidylinositol (PI) and DMSO were purchased from SigmaAldrich (St Louis, MO, USA). ICI 182,780 and Bicalutamide (Bic) were a generous gift from Zeneca Pharmaceuticals (Macclesfield, UK). The PI3K inhibitor LY294002 was used at $20 \mu \mathrm{M}$ and was obtained from Calbiochem (La Jolla, CA, USA). Dulbecco's Modified Eagle Medium (DMEM) and DMEM: Nutrient mixture F-12 (Ham) (1:1) (DMEM/F-12) were from Invitrogen (Carlsbad, CA, USA). Foetal bovine serum (FBS) was from BioWhittaker (East Rutherford, NJ, USA) and was heat inactivated before use. Protein
A/G plus agarose was from Santa Cruz Biotechnology (Santa Cruz, CA, USA). Antibodies used in this study were: PKB/AKT1/2 (559028), phospho-PKB/AKT (550747) and p85-PI3-kinase (610045) from Becton-Dickinson (San Jose, CA, USA), p85-PI3kinase (06497) from Upstate Biotechnology (Waltham, MA, USA), $\mathrm{AR} A b-1, \mathrm{ER} \alpha \mathrm{Ab}-10$ (immunoprecipitation) and $\mathrm{ER} \alpha$ Ab-16 (immunoblotting) from NeoMarkers (Fremont, CA, USA), $\beta$-actin (A2066) from Sigma-Aldrich and from MP-Biomedicals (Solon, OH, USA) (69100) and GSK-3 (9331) and p-PKB/AKT (4058) from Cell Signaling (Danvers, MA, USA). The antibody against phospho-GSK-3 was a generous gift from Dr Dario Alessi (University of Dundee, UK).

\section{Human prostate and breast cancer cells and prostate cancer primary cell cultures}

The human tumour cell lines used in this study were purchased from the American Type Culture Collection (Manassas, VA, USA). Prostate cancer androgen-sensitive LNCaP and androgen-insensitive PC-3 cell lines were cultured in DMEM/F-12 supplemented with $10 \%$ heat-inactivated FBS, 100 units $/ \mathrm{ml}$ penicillin G, $100 \mu \mathrm{g} \mathrm{ml}^{-1}$ streptomycin and $30 \mu \mathrm{g} \mathrm{ml}^{-1}$ amphotericin B. Breast cancer cell lines MCF-7 (oestrogen responsive) and MDA-MB-231 (oestrogen unresponsive) were grown in DMEM supplemented with $10 \%$ heat-inactivated FBS, $2 \mathrm{mM} \mathrm{L}$-glutamine, 100 units $\mathrm{ml}^{-1}$ penicillin $\mathrm{G}, 100 \mu \mathrm{g} \mathrm{ml}^{-1}$ streptomycin and $30 \mu \mathrm{g} \mathrm{ml}^{-1}$ amphotericin B. Treatments with trans-RES (in DMSO) were carried out for $36 \mathrm{~h}$ with the addition of fresh RES and culture medium at $24 \mathrm{~h}$. In experiments requiring steroid-free conditions, cells were maintained for 5 days in phenol red-free DMEM:F12 $(1: 1)$ supplemented with charcoal-stripped $10 \%$ FBS.

Human prostate cancer biopsies were obtained from patients scheduled for radical prostatectomy at the Clinical Hospital of the University of Chile. Informed consent was obtained from the patient's guardian and the experimental protocol approved by the ethics committee of the Institution. Primary cultures were established and characterised from seven prostate tumours as described (Castellon et al, 2005). Briefly, small tissue fragments were digested in an enzymatic mixture containing $2.5 \mathrm{mg} \mathrm{m}^{-1}$ collagenase, $1 \mathrm{mg} \mathrm{ml}^{-1}$ hyaluronidase and $0.01 \mathrm{mg} \mathrm{ml}^{-1}$ deoxyribonuclease for $2-3 \mathrm{~h}$ at $37^{\circ} \mathrm{C}$ in a shaking water bath. The epithelial cell aggregates were washed and further digested in collagenase solution for another $8-12 \mathrm{~h}$ under the same conditions. The small aggregates of prostate cancer cells obtained at the end of the incubation were mechanically dispersed, washed and seeded in cell culture plates. During the first days, culture medium was supplemented with 5\% FBS. To verify the tumoral phenotype of these primary cells, cultures were stained by immunocytochemistry for the malignant epithelial marker PCTA-1. Close to $90 \%$ of the cells were positive for PCTA-1, thus revealing their transformed status. Detailed description of the isolation, culturing and characterisation of these primary cultures have been published elsewhere (Sanchez et al, 2005; Castellon et al, 2006, 2005).

\section{Immunoprecipitation and associated PI3-kinase activity}

Androgen- and oestrogen receptor-associated PI3K activity was determined in $\mathrm{AR}$ and $\mathrm{ER} \alpha$ immunoprecipitates by measuring the in vitro phosphorylation of PI into $\mathrm{L}$ - $\alpha$-phosphatidylinositol-3phosphate as described (Pozo-Guisado et al, 2004). LNCaP and PC-3 cells growing in complete or steroids-depleted medium were treated for $36 \mathrm{~h}$ with RES and then lysed on ice for $15 \mathrm{~min}$ with $500 \mu \mathrm{l}$ IP buffer $(20 \mathrm{~mm}$ Tris- $\mathrm{HCl} \mathrm{pH} \mathrm{7.4,50} \mathrm{mm} \mathrm{NaCl,} 1 \%$ Nonidet P-40) containing $10 \mathrm{~mm}$ EDTA, $1 \mathrm{~mm}$ sodium orthovanadate, $50 \mathrm{~mm} \mathrm{NaF}, 0.5 \mathrm{~mm}$ phenyl-methyl sulphonyl fluoride (PMSF) and $4 \mu \mathrm{g} \mathrm{ml}^{-1}$ Complete protease inhibitor cocktail (Roche, Nutley, NJ, USA). Lysates were centrifuged at $15000 \mathrm{~g}$ for $15 \mathrm{~min}$ at $4^{\circ} \mathrm{C}$. Protein concentration was determined in the supernatants using 
the Coomassie Plus protein assay reagent (Pierce, Rockford, IL, USA) and bovine serum albumin as standard. One milligram of protein from freshly prepared extracts was used for each immunoprecipitation. $\mathrm{AR}$ and $\mathrm{ER} \alpha$ were immunoprecipitated overnight at $4{ }^{\circ} \mathrm{C}$ with $1 \mu \mathrm{g}$ anti-AR Ab-1 or $1.5 \mu \mathrm{g}$ anti-ER $\alpha \mathrm{Ab}$ 10 antibodies, respectively. Next, $25 \mu$ l of protein A/G plus-agarose beads were added and the samples incubated for an additional $1 \mathrm{~h}$ at $4{ }^{\circ} \mathrm{C}$. Beads were washed twice with each of the following buffers: buffer A (25 mm Tris- $\mathrm{HCl}$ pH 7.5, 1\% Nonidet P-40, 0.1 mm sodium orthovanadate); buffer B (100 mM Tris- $\mathrm{HCl} \mathrm{pH} \mathrm{7.5,} 0.1 \mathrm{~mm}$ sodium orthovanadate, $1 \mathrm{~mm}$ EDTA, $0.5 \mathrm{M} \mathrm{LiCl})$; buffer C (25 mM Tris- $\mathrm{HCl}$ $\mathrm{pH} 7.5,150 \mathrm{~mm} \mathrm{NaCl}, 1 \mathrm{~mm}$ EDTA). To measure AR- or ER $\alpha$ associated PI3K activity, $30 \mu \mathrm{g}$ PI (reconstituted and sonicated in $25 \mathrm{~mm}$ HEPES pH 7.5, $1 \mathrm{~mm}$ EDTA) were pre-incubated with the beads for $15 \mathrm{~min}$ at $4^{\circ} \mathrm{C}$. Enzymatic reactions were performed at room temperature for $30 \mathrm{~min}$ in $15 \mathrm{~mm}$ HEPES $\mathrm{pH} 7.6$, $10 \mathrm{mM} \mathrm{MgCl}_{2}, 0.5 \mathrm{~mm}$ EGTA, $40 \mu \mathrm{m}$ nonlabelled ATP and $10 \mu \mathrm{Ci}$ $\left[{ }^{32} \mathrm{P}\right]-\gamma \mathrm{ATP}$ (sp. act., $6000 \mathrm{Ci} \mathrm{mmol}^{-1}$ ). Proteins were then denatured by adding $400 \mu \mathrm{l}$ of a chloroform-methanol solution $(1: 2)$ in $1 \% \mathrm{HCl}$, plus $125 \mu \mathrm{l}$ chloroform and $125 \mu \mathrm{l} 10 \mathrm{~mm} \mathrm{HCl}$. Samples were centrifuged and the organic phase washed once with $500 \mu \mathrm{l}$ of methanol: $100 \mathrm{~mm} \mathrm{HCl}(1: 1)$ plus $2 \mathrm{~mm}$ EDTA. The organic phase was recovered, dried under nitrogen and resuspended in $30 \mu \mathrm{l}$ chloroform. Phosphorylated lipids were resolved by thin layer chromatography (TLC) using 60F254 silicagel plates (Merck, Whitehouse Station, NJ, USA) and a solution composed of chloroform:methanol:ammonia: water $(120: 94: 4: 23.2)$ as mobile phase. TLC plates were exposed in a Molecular Imager FX system (Bio-Rad Labs, Hercules, CA, USA) and analysed using the Quantity One software (Bio-Rad Labs). To determine the interaction between $\mathrm{AR}$ and $\mathrm{ER} \alpha$ with PI3K, proteins immunoprecipitated by the Ab-1 or Ab-16 antibodies were analysed by SDS-PAGE and Western immunobloting using a p85/PI3K-specific antibody.

\section{SDS-PAGE and Western immunobloting}

After treatment with RES, cells were washed with cold PBS and lysed in ice-cold lysis buffer (50 mm Tris- $\mathrm{HCl}$ pH 7.5, 2 mM EDTA, $2 \mathrm{~mm}$ EGTA, $10 \mathrm{~mm} \beta$-glycerophosphate, $150 \mathrm{~mm} \mathrm{NaCl}, 0.5 \%$ Nonidet P40, $1 \mathrm{~mm}$ PMSF, $1 \mathrm{~mm} \mathrm{NaF,} 1 \mathrm{~mm}$ DTT, $1 \% \quad \beta$ mercaptoethanol and $4 \mu \mathrm{g} \mathrm{ml}^{-1}$ Complete protease inhibitor cocktail (Roche, Nutley, NJ, USA). Lysates were centrifuged at $15000 \mathrm{~g}$ for $15 \mathrm{~min}$ at $4{ }^{\circ} \mathrm{C}$ and protein concentration determined in the supernatants using the Coomassie Plus protein assay reagent (Pierce, Rockford, IL, USA) and bovine serum albumin as standard. Fifteen micrograms of protein were mixed with SDS sample buffer, denatured and electrophoresed in 10 or $12 \%$ SDS-PAGE gels. Gels were transferred to nitrocellulose membranes by electroblotting and blocked for $2 \mathrm{~h}$ at room temperature in TBS-T (50 mM Tris- $\mathrm{HCl}$ pH 7.5, $150 \mathrm{~mm} \mathrm{NaCl,} \mathrm{0.2 \%} \mathrm{Tween-20)}$ containing $7 \%$ nonfat milk. Blots were sequentially incubated with the primary and secondary antibodies, washed in TBS-T and revealed using the Super-signal luminol substrate (Pierce, Rockford, IL, USA) and a chemiluminescence-imaging screen (Bio-Rad, Hercules, CA, USA). The screen was scanned using a Molecular Imager FX system from Bio-Rad (Hercules, CA, USA). For reprobing, blots were stripped by incubation in $100 \mathrm{~mm}$ Tris$\mathrm{HCl}, \mathrm{pH} 7.4,100 \mathrm{~mm} \beta$-mercaptoethanol and $2 \%$ SDS at $50^{\circ} \mathrm{C}$ for $30 \mathrm{~min}$.

\section{Statistical analysis}

Data are expressed as mean \pm s.e.m. Statistical comparison between treatments was carried out using GraphPad Prism 4.0 software (GraphPad, San Diego, CA, USA). One-way ANOVA followed by Dunn test were applied. ${ }^{\star} P<0.05$ and ${ }^{\star *} P<0.01$.

\section{RESULTS}

\section{RES treatment did not affect p85/PI3K levels but it decreased $A R$ and $E R \alpha$ protein expression in $\mathrm{LNCaP}$ and PC-3 cells}

The main goal of this study was to analyse whether the antiproliferative activity of RES in human prostate cancer cells could be mediated by inhibition of the AR- and ER $\alpha$-dependent PI3K pathways. The effect of RES on AR- and ER $\alpha$-dependent signalling was analysed after $36 \mathrm{~h}$ of treatment, as no significant apoptosis was observed in short-term (e.g. $30 \mathrm{~min}$ ) treatments (Benitez et al, 2007). Considering that the interaction between cytosolic steroid receptors (e.g. ER $\alpha$ ) and PI3K presumably takes place through p85 (Simoncini et al, 2000), we first determined if RES treatment could decrease protein levels for p85/PI3K, AR and $\mathrm{ER} \alpha$. Concentrations of RES up to $150 \mu \mathrm{M}$ did not significantly decrease endogenous p85 protein in androgen-responsive LNCaP or in androgen-insensitive PC-3 cells (Figure 1A and B). Regarding AR status in LNCaP, RES treatment induced a concentrationdependent decrease in receptor levels that was more pronounced at the highest concentration used of $150 \mu \mathrm{M}$ (Figure 1C). In PC-3, an androgen-insensitive prostate cancer cell line not expressing AR but having ER $\alpha$ (Lau et al, 2000), RES treatment also produced a concentration-dependent reduction in $\mathrm{ER} \alpha$ with a maximum effect at $100-150 \mu \mathrm{M}$ (Figure 1D). Thus, in our experimental conditions, RES did not significantly influence p85 but decreased the cellular levels of $\mathrm{AR}$ and $\mathrm{ER} \alpha$, an effect that could alter their likely interaction with the PI3K enzyme.

\section{AR and ER $\alpha$ interacted with p85/PI3K in LNCaP and PC-3 cells and RES did not affect such interactions}

It was shown that the cytosolic ER $\alpha$ interacted with PI3K in cancer cells (Simoncini et al, 2000; Pozo-Guisado et al, 2004). To determine if a similar mechanism was taking place in LNCaP and PC-3 prostate cancer cells, co-immunoprecipitation experiments were performed using specific antibodies for AR and $\mathrm{ER} \alpha$ (Figure 2). In the absence of RES (basal cell conditions), the AR antibody was able to immunoprecipitate p85 in LNCaP (Figure 2A, lower blot, lane 1 and graph) and the ER $\alpha$ antibody to immunoprecipitate this kinase in PC-3 (Figure 2B, lower blot, lane 1 and graph). The AR-p85 complexes were specific, as they were not recovered in AR-negative PC-3 cells (Figure 2A, lower panel, lane 8). Similarly, the ER $\alpha-\mathrm{p} 85$ complexes found in PC-3 were specific, as they could be observed in ER $\alpha$-positive MCF-7 but not in ER $\alpha$-negative MDA-MB-231 breast tumour cells (Figure 2B, lower blot, lanes 8 and 10, respectively). Reasonably, the levels of p85 bound to AR in LNCaP (Figure $2 \mathrm{~A}$, lower blot, compare lanes 1,7 and 9) or to ER $\alpha$ in PC-3 cells (Figure 2B, lower blot, compare lanes 1, 7, 9 and 11) were significantly lower than the total cellular content of p85, indicating that only an small fraction of kinase was interacting with these steroid receptors. Interestingly, treatment with RES up to $150 \mu \mathrm{M}$ did not significantly affect p85 interaction with $\mathrm{AR}$ in LNCaP or with $\mathrm{ER} \alpha$ in PC-3 cells (Figure $2 \mathrm{~A}$ and $\mathrm{B}$, lower blots, lanes 1-6), suggesting that the decrease in AR and $\mathrm{ER} \alpha$ protein levels at high concentrations of RES (Figure 1C and D) was not a limiting factor in the formation of complexes between these steroid receptors and PI3K.

\section{RES modulated the AR- and ER $\alpha$-associated PI3K activity} in LNCaP and PC-3 prostate tumour cells

Previous studies have shown that ER $\alpha$ activation increased PI3K signalling in endothelial cells (Simoncini et al, 2000) and that RES has oestrogenic and anti-oestrogenic activities ( $\mathrm{Lu}$ and Serrero, 1999; Bowers et al, 2000; Bhat and Pezzuto, 2001; Bhat et al, 2001) that could help explain its effects on the ER $\alpha$-associated PI3K 
A
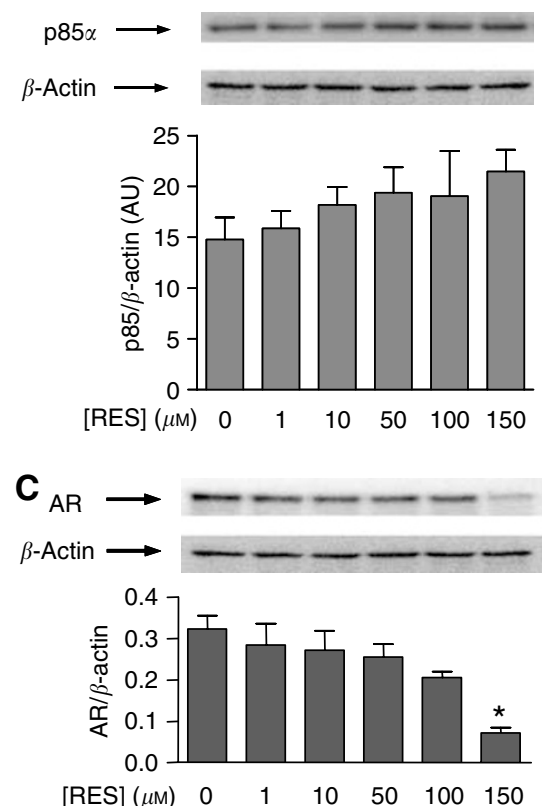

B
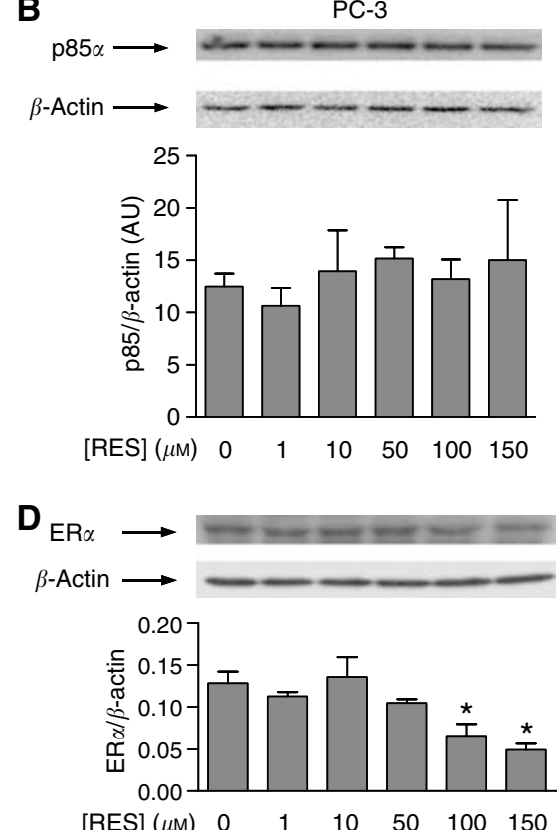

Figure I RES does not significantly affect p85/PI3K but decreases AR and ER $\alpha$ levels in LNCaP and PC-3 cells. LNCaP (A, C) and PC-3 (B, D) were left untreated (0, DMSO) or treated with I, 10, 50, 100 or I $50 \mu \mathrm{M}$ RES for $36 \mathrm{~h}$. Total protein extracts were obtained and analysed for p85/PI3K (A, B), AR (C) or $E R \alpha(\mathbf{D})$ protein expression by Western immunobloting using specific antibodies. The level of $\beta$-actin was also determined to account for protein quantitation and equal loading. p85/PI3K, AR and ER $\alpha$ expression were quantitated and normalised by $\beta$-actin in at least three different cultures. Data shown are mean \pm s.e. The difference with respect to untreated cultures (DMSO) is significant at $P<0.05$ (*).

activity in MCF-7 breast tumour cells (Pozo-Guisado et al, 2004). Based on these results, and as p85/PI3K interacted with AR and $\mathrm{ER} \alpha$ in LNCaP and PC-3 cells, we have analysed if this phytoalexin could inhibit the PI3K activity associated to these receptors. In basal LNCaP, PI3K activity could be detected in AR immunoprecipitates (Figure $3 \mathrm{~A}$, control), indicating that this pathway was active under normal culture conditions. This kinase activity was dependent not only on the interaction between AR and PI3K but also on the activity of the receptor, as it could be increased by treatment with the AR ligand DHT and decreased below basal levels by co-treatment with DHT plus the antagonist Bic (Figure 3A, Bic + DHT). Further, treatment with $150 \mu \mathrm{m}$ RES for 30 min induced a reproducible decrease in AR-associated PI3K activity (Figure 3A, RES). We then determined the effect of increasing concentrations of RES for $36 \mathrm{~h}$ on the AR-dependent $\mathrm{PI} 3 \mathrm{~K}$ activity in LNCaP cells growing in steroids-depleted medium. RES induced a concentration-dependent inhibition of PI3K activity that reached very low levels at $150 \mu \mathrm{M}$ (Figure 3B). This kinase activity was produced by $\mathrm{PI} 3 \mathrm{~K}$, as it could be blocked by its specific antagonist LY294002 (Figure 3B, LY). A similar titration curve was obtained in LNCaP cells cultured in complete medium (Figure $3 \mathrm{C}$ ), suggesting that FBS components did not significantly affect the AR-associated PI3K activity. Androgen-insensitive PC-3 cells, as expected, had only a residual level of AR-dependent PI3K activity (Figure 3C, PC3).

With respect to ER $\alpha$-expressing PC-3 cells (Figure 4), a constitutive level of PI3K activity was detected in ER $\alpha$ immunoprecipitates, indicating that oestrogens could regulate the PI3K pathway in androgen-insensitive prostate tumour cells (Figure $4 \mathrm{~A}$, control). In agreement, the specific ER $\alpha$ antagonist ICI 182,780 blocked such induction (Figure 4A, ICI). Treatment with $150 \mu \mathrm{M}$ RES for $30 \mathrm{~min}$ also inhibited the ER $\alpha$-associated PI $3 \mathrm{~K}$ activity (Figure 4A, RES), suggesting that this chemopreventive molecule had anti-oestrogenic activity in PC-3 cells. In addition, RES treatment for $36 \mathrm{~h}$ produced a concentration-dependent inhibition of the ER $\alpha$-dependent PI3K activity in steroids-depleted medium (Figure 4B). This kinase activity was due to PI3K, as it was markedly inhibited by its specific antagonist LY294002 and ER $\alpha$ dependent, because it was present in ER $\alpha$-positive MCF-7 but not in ER $\alpha$-negative MDA-MB-231 breast cancer cells (Figure 4B). In complete medium, RES treatment also inhibited the ER $\alpha$ dependent PI3K activity in a concentration-dependent manner (Figure 4C). Thus, LNCaP and PC-3 cells had an endogenous steroid receptor-dependent PI3K activity that could be modulated by RES through inhibition of $\mathrm{AR}$ and $\mathrm{ER} \alpha$ receptors.

\section{RES modulated PKB/AKT and GSK-3 phosphorylation and cyclin D1 levels in LNCaP and PC-3 cells with a pattern similar to that of PI3K activity}

One of best-characterised downstream targets of PI3K is PKB/AKT, which becomes activated by PDK1-dependent phosphorylation (Alessi et al, 1997; Engelman et al, 2006). Therefore, we next analysed if RES, through modulation of PI3K, could affect PKB/ AKT and GSK-3 phosphorylation and cyclin D1 levels. After normalisation by total $\mathrm{PKB} / \mathrm{AKT}$ protein, it was found that RES significantly decreased $\mathrm{PKB} / \mathrm{AKT}$ phosphorylation in LNCaP cells, particularly at concentrations above $100 \mu \mathrm{M}$ (Figure 5A); in PC-3 cells, although $\mathrm{PKB} / \mathrm{AKT}$ phosphorylation was also reduced, the effect was less pronounced (Figure 5B). Thus, inhibition of PI3K activity by RES resulted in a concentration-dependent decrease in $\mathrm{PKB} / \mathrm{AKT}$ phosphorylation. Among the known targets of $\mathrm{PKB} /$ AKT, GSK-3 is a relevant signalling molecule controlling the level of cell cycle regulatory proteins. In agreement with the lower levels of $\mathrm{PKB} / \mathrm{AKT}$ activation, RES also decreased GSK-3 phosphorylation in both LNCaP (Figure 6A) and PC-3 cells (Figure 6B). As GSK-3 becomes inactivated by phosphorylation, these results indicated that RES progressively turned GSK-3 to an activated (dephosphorylated) state. Again, this effect was apparently more pronounced in LNCaP than in PC-3 cells (Figure 6A and $\mathrm{B}$ ). 
A

LNCaP
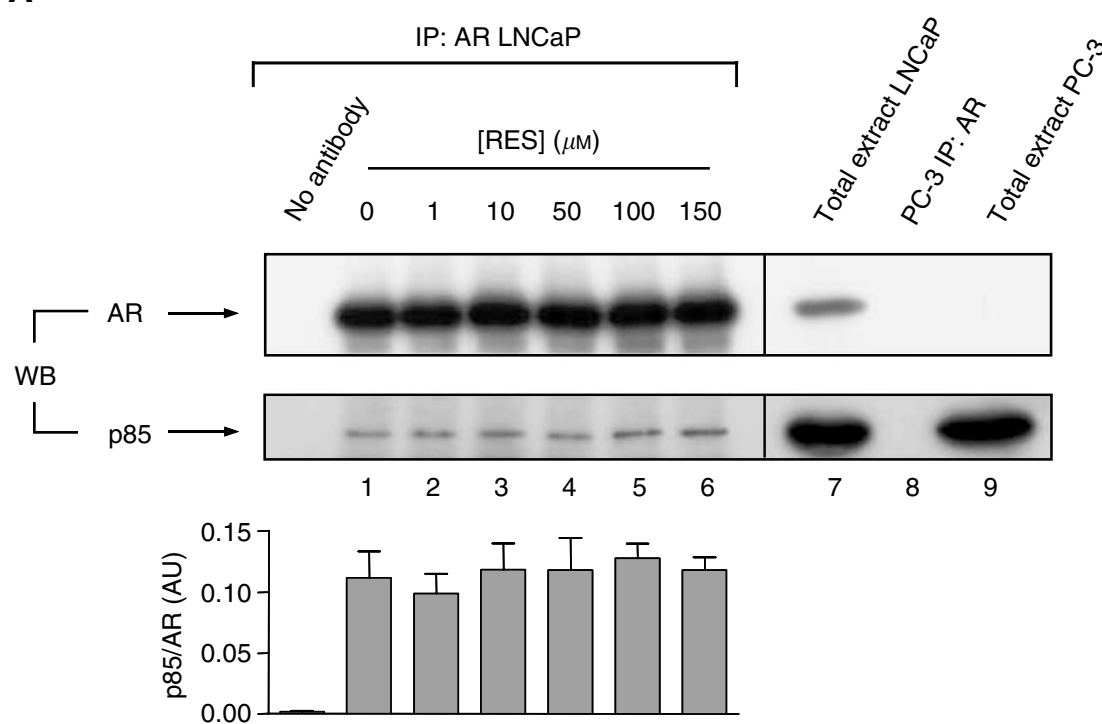

B

PC-3
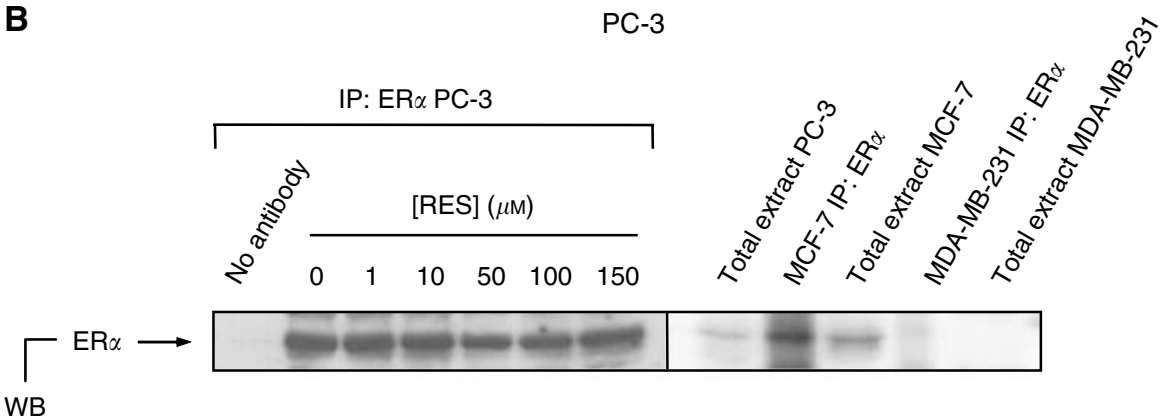

WB
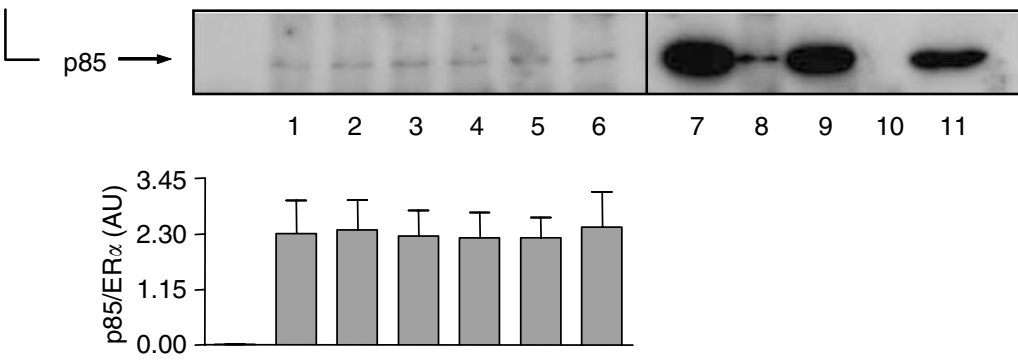

Figure 2 Steroid receptors AR and ER $\alpha$ interact with P85/PI3K in LNCaP and PC-3 prostate cancer cells and such interaction is not altered by RES treatment. LNCaP $(\mathbf{A})$ and PC-3 $(\mathbf{B})$, growing in complete medium, were treated with the indicated concentrations of RES for $36 \mathrm{~h}$ and I mg total cell extracts immunoprecipitated (IP) with anti-AR- or anti-ER $\alpha$-specific antibodies, respectively. The amount of p85/PI3K associated to each receptor was determined in the immunoprecipitates by Western immunobloting (WB) (lower blots in $\mathbf{A}$ and $\mathbf{B}$, lanes I -6). For quantitation, immunoprecipitated p85 was normalised by the amount of $\operatorname{AR}(\mathbf{A})$ or $E R \alpha(\mathbf{B})$ at each concentration of RES in three different cultures (lanes I-6). For LNCaP cells $(\mathbf{A})$ total cell extract was used as a positive control for AR and p85 expression (lane 7), whereas negative controls for this cell line included AR immunoprecipitation (lane 8) and total extract (lane 9) from androgen-insensitive PC-3 cells. For PC-3 (B), positive controls for ER $\alpha$ and p85 expression included total cell extracts from this cell line (lane 7) and from human breast tumour MCF-7 cells (lane 9); for ER $\alpha$ association to p85, immunoprecipitations were carried out in oestrogen-responsive MCF-7 (lower blot in B, lane 8). Negative controls were also included for ER $\alpha$ expression (lane II) and for its interaction with p85 (lane 10) using oestrogen-unresponsive human breast tumour MDA-MB-23I cells. As an additional negative control, immunoprecipitations were carried out in the absence of AR or ER $\alpha$ antibodies (no antibody in $\mathbf{A}$ and $\mathbf{B}$ )

Endogenous cyclin D1 levels are controlled by GSK-3 through a mechanism by which the active kinase phosphorylates and targets cyclin D1 for proteasomal degradation. In agreement with increased GSK-3 activity, cyclin D1 protein content was reduced by RES in a concentration-dependent manner, and more strongly in LNCaP (Figure 7A) than in PC-3 cells (Figure 7B). These data strongly suggest that RES inhibited the AR- and ER $\alpha$-associated PI3K activities in LNCaP and PC-3 cells and that they resulted in lower PKB/AKT activity, increased GSK-3 activation and decreased cyclin D1 protein levels.

\section{RES decreased $\mathrm{PKB} / \mathrm{AKT}$ phosphorylation in primary cultures of human prostate tumours}

To confirm and to further validate the results obtained in human prostate tumour cell lines LNCaP and PC-3, we have also 
A

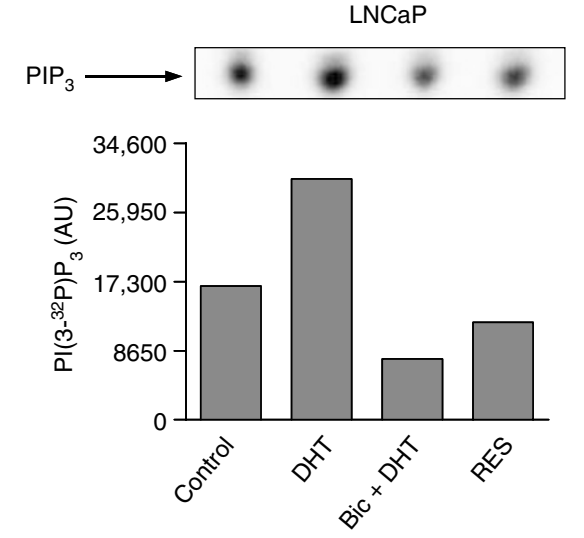

B
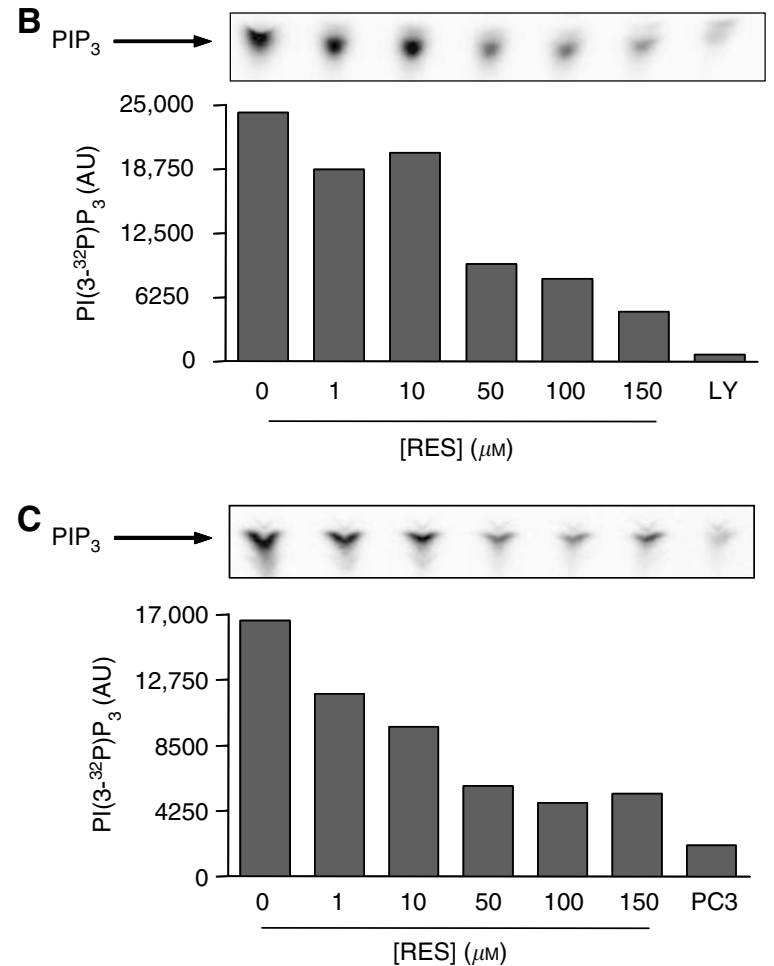

Figure 3 The AR-associated PI3K activity is modulated by RES in androgen-sensitive LNCaP cells. (A) LNCaP cells were cultured for 5 days in steroid-depleted medium and then treated with DMSO (control), $10^{-9} \mathrm{M}$ of the AR agonist DHT (30 min), $10^{-9} \mathrm{M} \mathrm{DHT}(30 \mathrm{~min})$ plus $10^{-4} \mathrm{M}$ of the AR antagonist Bic (30 min) or I $50 \mu \mathrm{M}$ RES $(30 \mathrm{~min}$ ). Aliquots of I $\mathrm{mg}$ total cell extract were immunoprecipitated with an AR-specific antibody and PI3K activity determined in the immunoprecipitates using $\mathrm{PI}$ as substrate. (B) PI3K activity was determined in AR immunoprecipitates obtained from cultures grown in steroid-depleted medium and left untreated (DMSO) or treated with I, 10, 50, 100 or I50 $\mu \mathrm{M}$ RES for $36 \mathrm{~h}$. Some cultures were treated with $20 \mu \mathrm{M}$ of the PI3K inhibitor LY294002 (LY). (C) PI3K activity was also determined in AR immunoprecipitates from cultures grown in complete medium and treated with 0 (DMSO), I, 10, 50, I00 or I $50 \mu \mathrm{M}$ RES. Androgen-insensitive PC-3 cells (PC3) were used as negative control. A representative experiment out of two is shown.

determined the effect of RES on PKB/AKT phosphorylation in primary cultures from human prostate tumours. The transformed phenotype of these cultures was confirmed by immunocytochemistry for the marker PCTA-1 as described (Sanchez et al, 2005; Castellon et al, 2006, 2005). $\mathrm{PKB} / \mathrm{AKT}$ was used as a reporter in the
A

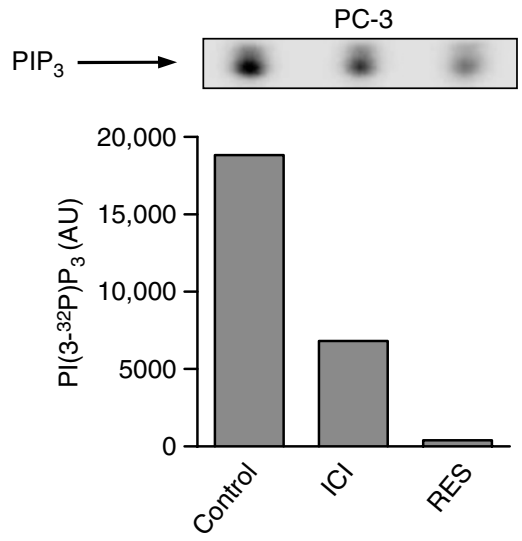

B
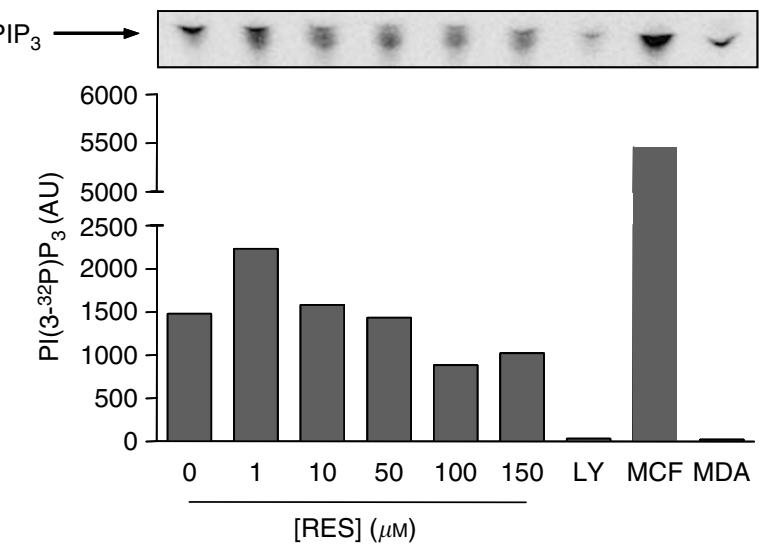

C
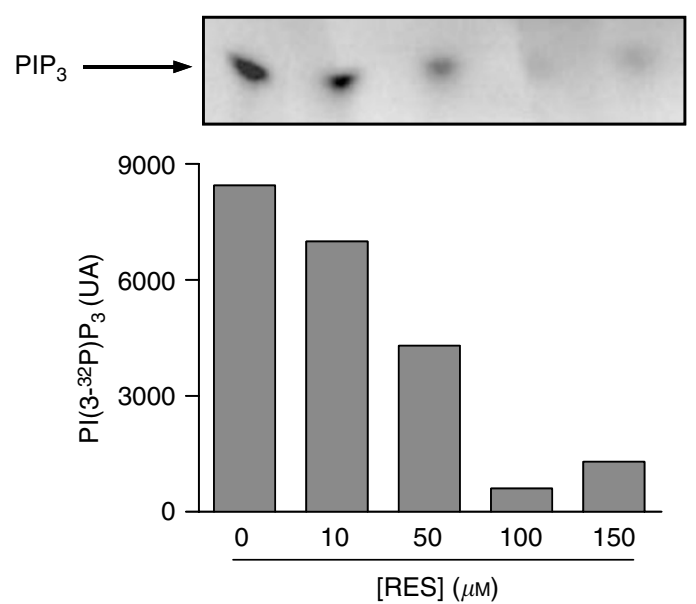

Figure 4 RES modulates the ER $\alpha$-associated PI3K activity in androgeninsensitive PC-3 cells. (A) PC-3 cells were cultured in steroid-depleted medium for 5 days and then treated with DMSO (control), I $\mu$ M of the ER $\alpha$ antagonist ICI I82,780 (30 min) or I $50 \mu \mathrm{M}$ RES (30 min). Total cell extracts were prepared and I mg protein immunoprecipitated with an ER $\alpha$-specific antibody. ER $\alpha$-associated PI3K activity was determined in the immunoprecipitates using Pl as substrate. (B) PC-3 cells growing in steroid depleted medium for 5 days were left untreated (DMSO) or treated with I, 10, 50, 100 or $150 \mu \mathrm{m}$ RES for $36 \mathrm{~h}$ and PI3K activity determined in ERo immunoprecipitates. Cells were also treated with $20 \mu \mathrm{M}$ of the PI3K inhibitor LY294002 (LY). As positive and negative controls, experiments were performed in $E R \alpha$ immunoprecipitates from $E R \alpha$-positive MCF-7 and ER $\alpha$-negative MDA-MB-23I breast cancer cells, respectively. (C) PC-3 cells were grown in complete medium and left untreated (DMSO) or treated with $10,50,100$ or $150 \mu \mathrm{M}$ RES for $36 \mathrm{~h}$. PI3K activity was determined in $\mathrm{ER} \alpha$ immunoprecipitates using $\mathrm{Pl}$ as substrate. A representative experiment from two is shown. 
A
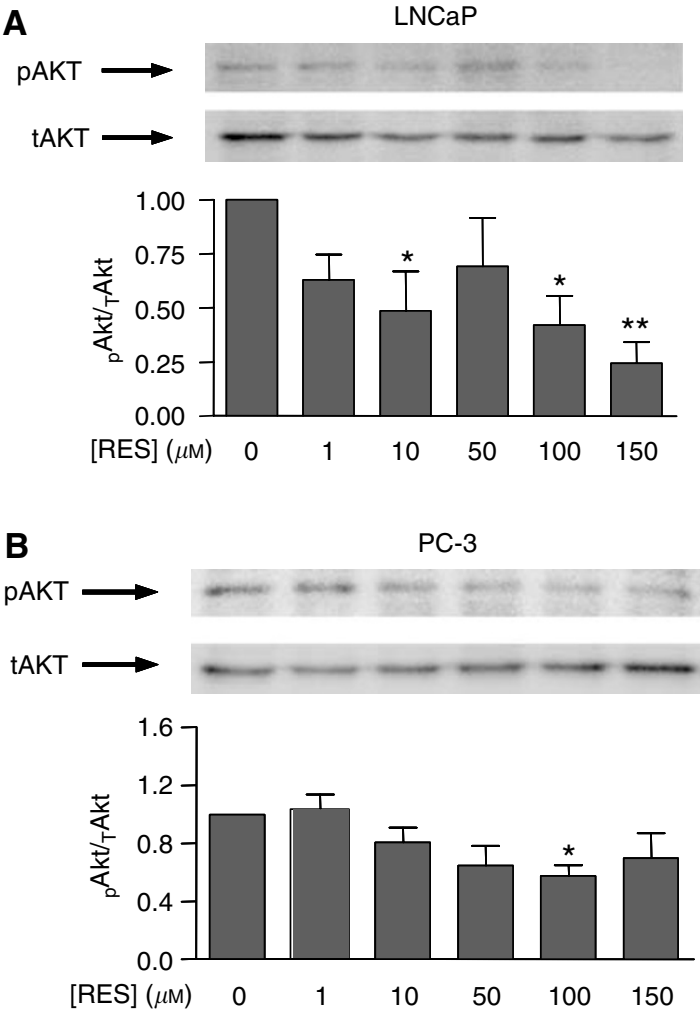

Figure 5 RES inhibition of the PI3K activity in LNCaP and PC-3 cells resulted in decreased PKB/AKT phosphorylation. LNCaP $(\mathbf{A})$ and PC-3 (B) cells were left untreated (DMSO) or treated with I, 10, 50, 100 or I50 $\mu \mathrm{M}$ RES for $36 \mathrm{~h}$ in complete medium. Protein extracts were analysed by Western immunobloting to detect the phosphorylated (pAKT) and the total PKB/AKT protein ( $\mathrm{A} A K T$ ). Data were quantitated by normalising $\mathrm{pPKB} /$ $A K T$ by $t P K B / A K T$ (PAKT/tAKT) and the results plotted against the concentration of RES. Data shown are mean + s.e. from three different cultures. The differences with respect to control cultures (DMSO) are significant at $P<0.05$ (*) or $P<0.01$ (**)

signalling pathway, as its degree of phosphorylation reflects the level of PI3K activity. RES did not significantly affect p85/PI3K protein levels (Figure 8A) in prostate tumour cells growing in primary culture, as previously observed for the cell lines analysed (see Figure 1). In primary cultures of prostate tumour cells, RES induced a concentration-dependent decrease in $\mathrm{PKB} / \mathrm{AKT}$ phosphorylation that closely resembled that found in $\mathrm{LNCaP}$ and $\mathrm{PC}-3$ cell lines (Figure 8B). Interestingly, a large degree of inhibition was observed at $100 \mu \mathrm{m}$ RES, indicating that these primary cells were very sensitive to this phytoalexin.

\section{DISCUSSION}

Among the many different chemopreventive natural compounds identified to date, RES has been, and actually is, the focus of intense investigation. Its ability to inhibit growth and to induce apoptotic cell death in a large series of tumour cells, its potential to be easily included in the diet, and its activity as co-adjuvant for some chemotherapeutic molecules, make RES a good candidate for chemoprevention and chemotherapy of human cancer. Prostate cancer is a form of this disease with one of the highest prevalence and mortality in the population, having a poor prognosis once it becomes refractory to chemotherapy and/or metastatic. A relevant additional factor that contributes to the progression of prostate

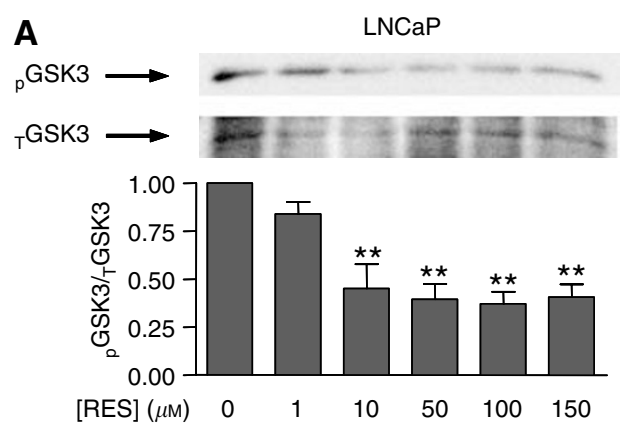

B

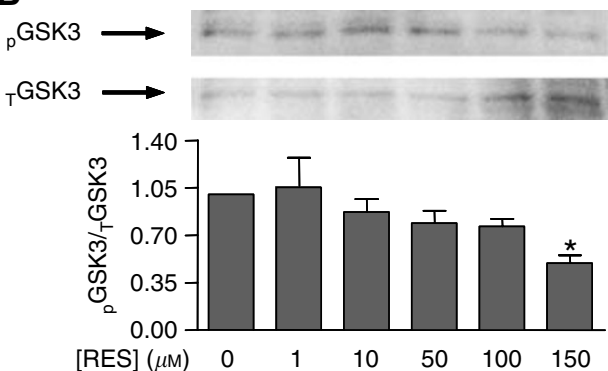

Figure 6 RES induces a pattern of GSK-3 phosphorylation in $\mathrm{LNCaP}$ and PC-3 cells that closely resembles that of PKB/AKT. LNCaP $(\mathbf{A})$ and PC-3 (B) were treated with DMSO, I, 10, 50, I00 or 150 $\mu \mathrm{M}$ RES for $36 \mathrm{~h}$ in complete medium. Total cell extracts were analysed for phosphorylated (pGSK3) and total GSK-3 (tGSK3) by Western immunobloting using specific antibodies. Phospho-GSK-3 was normalised by total GSK-3 protein at each concentration of RES. Data shown are mean \pm s.e. from at least three different experiments. The differences are statistically significant with respect to control values (DMSO) at $P<0.05$ (*) or $P<0.01$ (**).

cancer and that limits treatment efficacy is the ability of tumour cells to change from a hormone-responsive to a hormoneunresponsive phenotype. In this context, the fact that RES has anti-oestrogenic activity in hormone-responsive tumour cells (Lu and Serrero, 1999; Bowers et al, 2000; Bhat et al, 2001; Levenson et al, 2003) opens the possibility for this molecule to be useful in prostate cancer. Indeed, different laboratories have reported antiproliferative activity of RES in hormone-responsive LNCaP (Hsieh and Wu, 1999; Mitchell et al, 1999; Narayanan et al, 2003) and hormone-unresponsive PC-3 and DU-145 prostate cells (Hsieh and $\mathrm{Wu}, 1999$ ), albeit the former was more sensitive than the latter to cell death. This different potency of RES in prostate tumour cells could be related to downregulation of the expression and function of the AR in androgen-responsive LNCaP cells (Mitchell et al, 1999). Our data also support this different sensitivity of prostate tumour cells to RES, as the higher degree of cell death found in LNCaP with respect to PC-3 (Benitez et al, 2007) appears to correlate with a higher inhibition of PI3K activity in the former.

Non-nuclear functions have been described for steroid hormone receptors that emphasise their relevance in signalling pathways controlling proliferation and survival. In this context, androgens activated the PI3K pathway by inducing the interaction of AR with p85 (Sun et al, 2003), in a similar manner to that observed for the oestrogen-dependent activation of PI3K through ER $\alpha$ in endothelial cells (Simoncini et al, 2000). RES regulates the interaction between steroid hormone receptors and PI3K because concentrations of this molecule inducing apoptosis in MCF-7 also inhibited the ER $\alpha$-dependent PI3K pathway (Pozo-Guisado et al, 2004), and a recent report has shown that RES inhibited PKB/AKT phosphorylation in LNCaP cells (Aziz et al, 2006). 


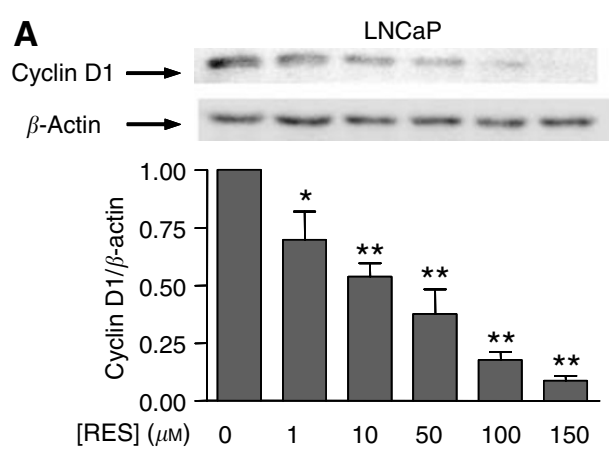

B
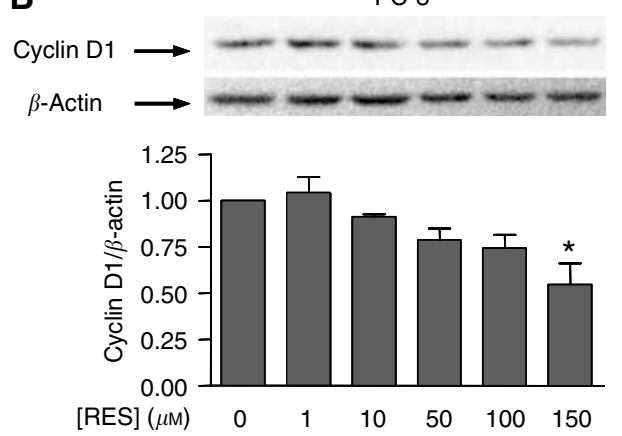

Figure 7 The GSK-3 target protein cyclin DI is affected by RES in LNCaP and PC-3 cells with a pattern similar to that of PKB/AKT. LNCaP (A) and PC-3 (B) cells were left untreated (DMSO) or treated with I, I0, 50 , 100 or $150 \mu \mathrm{M}$ RES for $36 \mathrm{~h}$ in complete medium. Protein extracts were analysed for cyclin DI levels by Western immunobloting using a specific antibody. The expression of $\beta$-actin was also determined to account for equal loading and protein quantitation. Cyclin DI was normalised by $\beta$-actin and the results plotted for each concentration of RES. Data are shown as mean \pm s.e. from three different cultures. The differences with respect to control cultures (DMSO) are significant at $P<0.05$ (*) or $P<0.01$ (**).

In our experimental conditions, RES did not significantly affect protein levels of $\mathrm{p} 85 / \mathrm{PI} 3 \mathrm{~K}$ in $\mathrm{LNCaP}$ or PC-3 cells, in contrast to a recent report showing a $40-50 \%$ reduction in $\mathrm{p} 85$ protein in LNCaP (Aziz et al, 2006). However, RES inhibited AR and ER $\alpha$ expression in LNCaP and PC-3 cells, respectively. The antiproliferative activity of RES in these cell lines (Benitez et al, 2007), if mediated through PI3K, would most probably produce a specific inhibition of the steroid receptor-associated PI3K (owing to the anti-oestrogenic potential of this molecule) than a global downregulation of cellular PI3K activity. Regardless the decrease in p85 expression, coimmunoprecipitation experiments revealed that none of the concentrations of RES used compromised AR- or $\mathrm{ER} \alpha$ interaction with $\mathrm{p} 85$ in $\mathrm{LNCaP}$ or $\mathrm{PC}-3$, indicating that inhibition of the steroid-receptor-dependent PI3K activity by RES was not due to changes in AR, ER $\alpha$ or p85 levels. In agreement, previous data showed that although RES decreased ER $\alpha$ protein levels in MCF-7, it did not affect the interaction between this receptor and p85/PI3K (Pozo-Guisado et al, 2004).

$\mathrm{AR}$ - and $\mathrm{ER} \alpha$-dependent PI3K activities were strongly inhibited by RES in LNCaP and PC-3 cells in a concentration dependentmanner in both, steroid-containing and steroid-depleted medium. As the interaction between $\mathrm{AR}$ and $\mathrm{ER} \alpha$ with $\mathrm{p} 85 / \mathrm{PI} 3 \mathrm{~K}$ was not affected by RES, the inhibition of PI3K in LNCaP and PC-3 was probably due to the anti-oestrogenic activity of this phytoalexin on both steroid receptors. It is interesting to note that short-term treatment $(30 \mathrm{~min})$ with high concentrations of RES significantly inhibited PI3K activity in LNCaP and PC-3 cells. Although in these
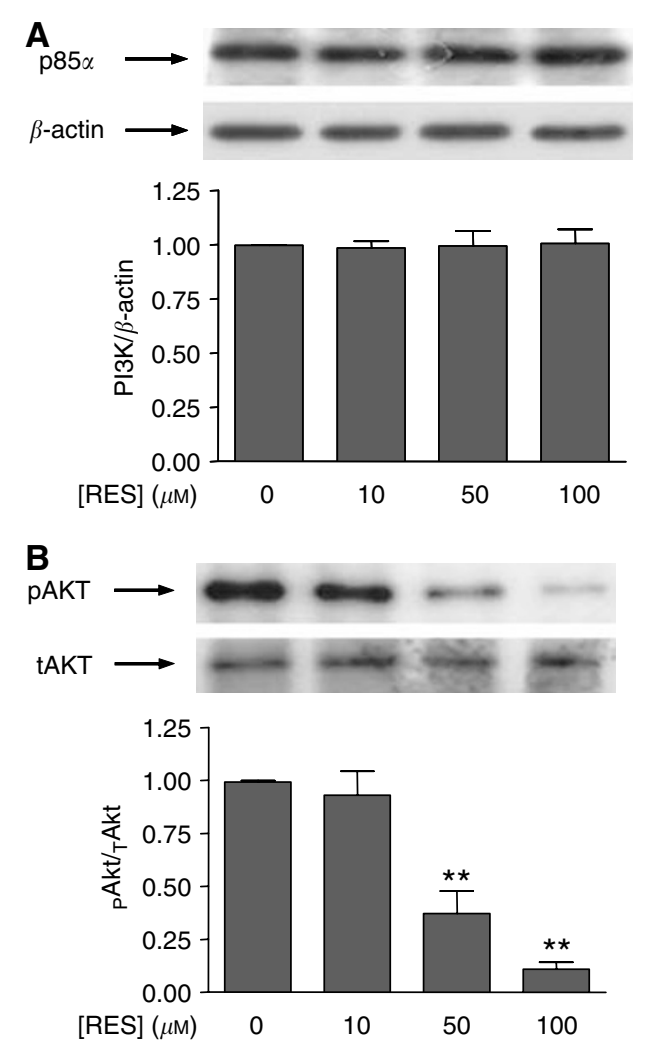

Figure 8 The effects of RES on P85/PI3K and PKB/AKT phosphorylation in cultured human primary prostate tumour cells closely resemble those observed in LNCaP and PC-3 cells. A total of seven biopsies from patients scheduled for radical prostatectomy were used to obtain primary cultures of prostate epithelial tumour cells. Cells were characterised as having a transformed phenotype as previously were indicated (Sanchez et al, 2005; Castellon et al, 2006, 2005). Cultures treated with DMSO, 10, 50 or $100 \mu \mathrm{M}$ RES for $36 \mathrm{~h}$ in complete medium. (A) Total protein extracts were analysed for p85/PI3K expression by Western immunobloting and the results normalised by $\beta$-actin levels. (B) Phosphorylated (pAKT) and total PKB/AKT (tAKT) were also determined by Western immunobloting and the amount of active protein (PAKT) normalised by the total PKB/AKT (tAKT). Data are shown as mean \pm s.e. The differences with respect to untreated control cultures are significant at $P<0.0$ I (**).

conditions RES did not induce a significant degree of cell death in either cell line (D Benitez, unpublished observations), it could be possible that the inhibition of PI3K is an early step in the mechanism for apoptosis induction by RES in steroid-dependent tumour cells. Thus, the question remains of whether a maintained inhibition of steroid receptor-associated PI3K activity is required for RES-induced cell death or if, once triggered, apoptosis proceeds irreversibly in the absence of RES.

A major target of $\mathrm{PI} 3 \mathrm{~K}$ is $\mathrm{PKB} / \mathrm{AKT}$, which signals to downstream proteins such as GSK-3 (Cantley, 2002; Engelman et al, 2006). Consistent with the inhibition of PI3K activity by RES, $\mathrm{PKB} / \mathrm{AKT}$ was inhibited, whereas GSK-3 was activated in a concentration-dependent manner in both LNCaP and PC-3. It is known that an increase in GSK-3 activity induces blockade of the cell cycle by promoting the degradation of G1/S regulators such as cyclin D1 (Scheid and Woodgett, 2001). Indeed, RES decreased cyclin D1 levels in either cell line, a result consistent with the ability of this phytoalexin to block DNA synthesis and to inhibit not only entry into S phase (Kuwajerwala et al, 2002) but also cell proliferation (Ratan et al, 2002). Interestingly, the effects of RES on 
$\mathrm{PKB} / \mathrm{AKT}, \mathrm{GSK}-3$ and cyclin D1 were more pronounced in LNCaP than in PC-3, again suggesting that this molecule, although able to antagonise $\mathrm{AR}$ and $\mathrm{ER} \alpha$ steroid receptors, could have a differential effectiveness on each one of them. Previous studies have also shown that RES inhibited more strongly cell growth and proliferation in LNCaP than in PC-3 (Hsieh and Wu, 1999). Further, inhibition of the PI3K signalling pathway by RES, at concentrations inducing apoptosis and through an ER $\alpha$-dependent mechanism, has been also reported in MCF-7 tumour cells (PozoGuisado et al, 2004).

A relevant aspect of our study is the analysis of primary cultures established from human prostate tumours biopsies. In close agreement to the results obtained in LNCaP and PC-3 cell lines, RES did not affect the expression of p85/PI3K in cultured human prostate tumour cells. Notably, however, RES induced a marked concentration-dependent inhibition of $\mathrm{PKB} / \mathrm{AKT}$ phosphorylation. Therefore, RES inhibited the PI3K pathway in primary prostate tumour cells in culture through a mechanism similar to that found in cell lines. These observations support LNCaP and PC-3 as model cell lines in these studies and highlight the PI3K pathway as a potential target for the antiproliferative activity of RES in human prostate cancer. A proposed model for RES-dependent inhibition of the AR- and ER $\alpha$-associated PI3K pathway is shown in Figure 9.

In summary, this work reveals that the AR- and $\mathrm{ER} \alpha$-dependent PI3K pathways are active in LNCaP and PC-3 human prostate tumour cells. Our data suggest that the antiproliferative activity of RES in androgen-responsive $\mathrm{LNCaP}$ and androgen-unresponsive PC-3 cells could be mediated, at least in part, by the antagonistic activity of this molecule on the AR and ER $\alpha$ that interact with the PI3K survival pathway. As it is plausible that the mechanism proposed here in tumour cell lines could also take place in human prostate tumours, we suggest that inhibition of steroid receptorassociated PI3K activity could represent a possible target for chemoprevention and for adjuvant chemotherapy involving RES. Additional in vivo studies and a detailed characterisation of this signalling pathway in human primary prostate tumours are required.

\section{REFERENCES}

Ahmad N, Adhami VM, Afaq F, Feyes DK, Mukhtar H (2001) Resveratrol causes WAF-1/p21-mediated G(1)-phase arrest of cell cycle and induction of apoptosis in human epidermoid carcinoma A431 cells. Clin Cancer Res 7: $1466-1473$

Alessi DR, James SR, Downes CP, Holmes AB, Gaffney PR, Reese CB, Cohen P (1997) Characterization of a 3-phosphoinositide-dependent protein kinase which phosphorylates and activates protein kinase Balpha. Curr Biol 7: $261-269$

Aziz MH, Nihal M, Fu VX, Jarrard DF, Ahmad N (2006) Resveratrol-caused apoptosis of human prostate carcinoma LNCaP cells is mediated via modulation of phosphatidylinositol 3'-kinase/Akt pathway and Bcl-2 family proteins. Mol Cancer Ther 5: 1335-1341

Banerjee S, Bueso-Ramos C, Aggarwal BB (2002) Suppression of 7,12dimethylbenz(a)anthracene-induced mammary carcinogenesis in rats by resveratrol: role of nuclear factor-kappaB, cyclooxygenase 2, and matrix metalloprotease 9. Cancer Res 62: 4945-4954

Basly JP, Marre-Fournier F, Le Bail JC, Habrioux G, Chulia AJ (2000) Estrogenic/antiestrogenic and scavenging properties of (E)- and (Z)resveratrol. Life Sci 66: 769-777

Benitez DA, Pozo-Guisado E, Alvarez-Barrientos A, Fernandez-Salguero PM, Castellon EA (2007) Mechanisms involved in resveratrol-induced apoptosis and cell cycle arrest in prostate cancer-derived cell lines. J Androl 28: 282-293

Bhat KP, Lantvit D, Christov K, Mehta RG, Moon RC, Pezzuto JM (2001) Estrogenic and antiestrogenic properties of resveratrol in mammary tumor models. Cancer Res 61: 7456-7463

Bhat KP, Pezzuto JM (2001) Resveratrol exhibits cytostatic and antiestrogenic properties with human endometrial adenocarcinoma (Ishikawa) cells. Cancer Res 61: 6137-6144

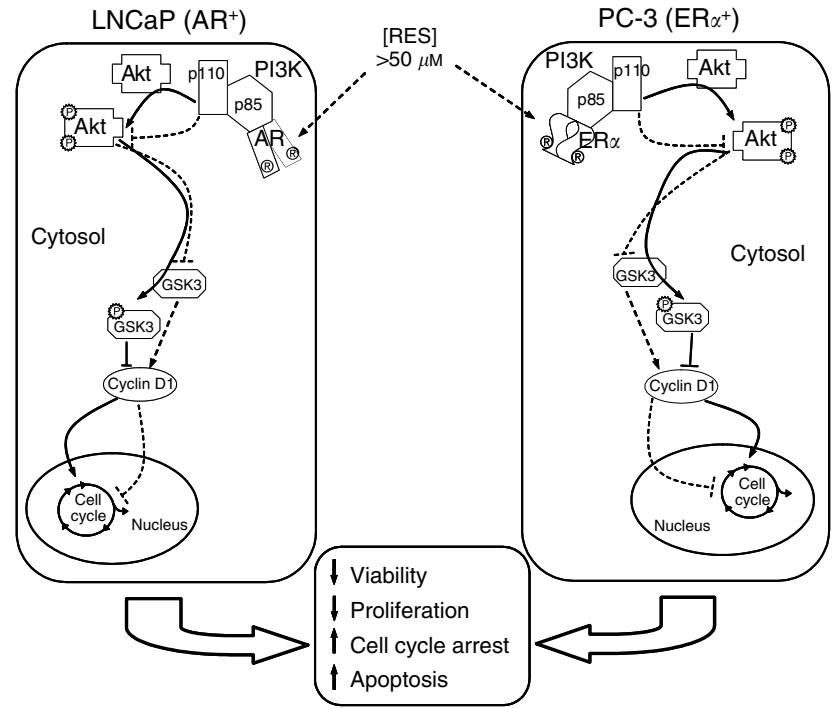

Figure 9 Proposed mechanism for RES induced apoptosis in LNCaP and PC-3 human prostate tumour cells. Concentrations of RES that induces apoptosis (RES $>50 \mu \mathrm{M}$ ) inhibits the AR- and ER $\alpha$-dependent PI3K activity in LNCaP and PC-3 cells, respectively. RES-dependent PI3K inhibition results in lower levels of PPKB/AKT and in a decrease in its activity. Downstream PKB/AKT, hypophosphorylated GSK-3 would contribute to decreased cyclin DI levels. Alteration of these pathways by RES would inhibit proliferation and increase apoptosis in an AR- or ER $\alpha$-dependent manner. Filled lines represent signal transduction in absence of RES, whereas dotted lines stand for the effects of RES on the same signalling events.

\section{ACKNOWLEDGEMENTS}

This work has been funded by Grant 2PR04A060 from the Junta de Extremadura (to P.F.-S.)

Bowers JL, Tyulmenkov VV, Jernigan SC, Klinge CM (2000) Resveratrol acts as a mixed agonist/antagonist for estrogen receptors alpha and beta. Endocrinology 141: 3657 - 3667

Cantley LC (2002) The phosphoinositide 3-kinase pathway. Science 296: $1655-1657$

Castellon E, Clementi M, Hitschfeld C, Sanchez C, Benitez D, Saenz L, Contreras H, Huidobro C (2006) Effect of leuprolide and cetrorelix on cell growth, apoptosis, and $\mathrm{GnRH}$ receptor expression in primary cell cultures from human prostate carcinoma. Cancer Invest 24: 261 - 268

Castellon E, Venegas K, Saenz L, Contreras H, Huidobro C (2005) Secretion of prostatic specific antigen, proliferative activity and androgen response in epithelial-stromal co-cultures from human prostate carcinoma. Int J Androl 28: $39-46$

Cross DA, Alessi DR, Cohen P, Andjelkovich M, Hemmings BA (1995) Inhibition of glycogen synthase kinase- 3 by insulin mediated by protein kinase B. Nature 378: 785-789

Dorrie J, Gerauer H, Wachter Y, Zunino SJ (2001) Resveratrol induces extensive apoptosis by depolarizing mitochondrial membranes and activating caspase- 9 in acute lymphoblastic leukemia cells. Cancer Res 61: $4731-4739$

Engelman JA, Luo J, Cantley LC (2006) The evolution of phosphatidylinositol 3-kinases as regulators of growth and metabolism. Nat Rev Genet 7: $606-619$

Gao S, Liu GZ, Wang Z (2004) Modulation of androgen receptor-dependent transcription by resveratrol and genistein in prostate cancer cells. Prostate 59: $214-225$

Gehm BD, McAndrews JM, Chien PY, Jameson JL (1997) Resveratrol, a polyphenolic compound found in grapes and wine, is an agonist for the estrogen receptor. Proc Natl Acad Sci USA 94: 14138-14143 
Hsieh TC, Wu JM (1999) Differential effects on growth, cell cycle arrest, and induction of apoptosis by resveratrol in human prostate cancer cell lines. Exp Cell Res 249: 109-115

Jang M, Cai L, Udeani GO, Slowing KV, Thomas CF, Beecher CW, Fong HH, Farnsworth NR, Kinghorn AD, Mehta RG, Moon RC, Pezzuto JM (1997) Cancer chemopreventive activity of resveratrol, a natural product derived from grapes. Science 275: 218-220

Joe AK, Liu H, Suzui M, Vural ME, Xiao D, Weinstein IB (2002) Resveratrol induces growth inhibition, S-phase arrest, apoptosis, and changes in biomarker expression in several human cancer cell lines. Clin Cancer Res 8: $893-903$

Kuwajerwala N, Cifuentes E, Gautam S, Menon M, Barrack ER, Reddy GP (2002) Resveratrol induces prostate cancer cell entry into s phase and inhibits DNA synthesis. Cancer Res 62: 2488-2492

Lau KM, LaSpina M, Long J, Ho SM (2000) Expression of estrogen receptor (ER)-alpha and ER-beta in normal and malignant prostatic epithelial cells: regulation by methylation and involvement in growth regulation. Cancer Res 60: $3175-3182$

Levenson AS, Gehm BD, Pearce ST, Horiguchi J, Simons LA, Ward III JE, Jameson JL, Jordan VC (2003) Resveratrol acts as an estrogen receptor (ER) agonist in breast cancer cells stably transfected with ER alpha. Int J Cancer 104: $587-596$

Lu R, Serrero G (1999) Resveratrol, a natural product derived from grape, exhibits antiestrogenic activity and inhibits the growth of human breast cancer cells. J Cell Physiol 179: 297-304

Marquez DC, Pietras RJ (2001) Membrane-associated binding sites for estrogen contribute to growth regulation of human breast cancer cells. Oncogene 20: 5420-5430

Mitchell SH, Zhu W, Young CY (1999) Resveratrol inhibits the expression and function of the androgen receptor in LNCaP prostate cancer cells. Cancer Res 59: $5892-5895$

Narayanan BA, Narayanan NK, Re GG, Nixon DW (2003) Differential expression of genes induced by resveratrol in LNCaP cells: P53-mediated molecular targets. Int J Cancer 104: 204-212

Pozo-Guisado E, Alvarez-Barrientos A, Mulero-Navarro S, Santiago-Josefat B, Fernandez-Salguero PM (2002) The antiproliferative activity of resveratrol results in apoptosis in MCF-7 but not in MDA-MB-231 human breast cancer cells: cell-specific alteration of the cell cycle. Biochem Pharmacol 64: 1375-1386
Pozo-Guisado E, Lorenzo-Benayas MJ, Fernandez-Salguero PM (2004) Resveratrol modulates the phosphoinositide 3-kinase pathway through an estrogen receptor alpha-dependent mechanism: relevance in cell proliferation. Int J Cancer 109: 167-173

Pozo-Guisado E, Merino JM, Mulero-Navarro S, Lorenzo-Benayas MJ Centeno F, Alvarez-Barrientos A, Fernandez-Salguero PM (2005) Resveratrol-induced apoptosis in MCF-7 human breast cancer cells involves a caspase-independent mechanism with downregulation of Bcl-2 and NF-kappaB. Int J Cancer 115: 74-84

Ratan HL, Steward WP, Gescher AJ, Mellon JK (2002) Resveratrol - a prostate cancer chemopreventive agent? Urol Oncol 7: 223-227

Sanchez C, Clementi M, Benitez D, Contreras H, Huidobro C, Castellon E (2005) Effect of GnRH analogs on the expression of TrkA and p75 neurotrophin receptors in primary cell cultures from human prostate adenocarcinoma. Prostate 65: 195-202

Scheid MP, Marignani PA, Woodgett JR (2002) Multiple phosphoinositide 3-kinase-dependent steps in activation of protein kinase B. Mol Cell Biol 22: $6247-6260$

Scheid MP, Woodgett JR (2001) PKB/AKT: functional insights from genetic models. Nat Rev Mol Cell Biol 2: $760-768$

Sengottuvelan M, Viswanathan P, Nalini N (2006) Chemopreventive effect of trans-resveratrol - a phytoalexin against colonic aberrant crypt foci and cell proliferation in 1,2-dimethylhydrazine induced colon carcinogenesis. Carcinogenesis 27: 1038-1046

Simoncini T, Hafezi-Moghadam A, Brazil DP, Ley K, Chin WW, Liao JK (2000) Interaction of oestrogen receptor with the regulatory subunit of phosphatidylinositol-3-OH kinase. Nature 407: 538-541

Stephens L, Anderson K, Stokoe D, Erdjument-Bromage H, Painter GF, Holmes AB, Gaffney PR, Reese CB, McCormick F, Tempst P, Coadwell J, Hawkins PT (1998) Protein kinase B kinases that mediate phosphatidylinositol 3,4,5-trisphosphate-dependent activation of protein kinase B. Science 279: $710-714$

Sun M, Yang L, Feldman RI, Sun XM, Bhalla KN, Jove R, Nicosia SV, Cheng JQ (2003) Activation of phosphatidylinositol 3-kinase/Akt pathway by androgen through interaction of p85alpha, androgen receptor, and Src. J Biol Chem 278: $42992-43000$

Whitsett Jr TG, Carpenter DM, Lamartiniere CA (2006) Resveratrol, but not EGCG, in the diet suppresses DMBA-induced mammary cancer in rats. J Carcinog 5: 15 